\title{
Talbotiella cheekii (Leguminosae: Detarioideae), a new tree species from Guinea
}

\author{
Xander M. van der Burgt ${ }^{1}$ (D) Denise Molmou ${ }^{2}$, Almamy Diallo², Gbamon Konomou ${ }^{2}$, Pepe M. Haba ${ }^{3}$ \& \\ Sékou Magassouba
}

Summary. Talbotiella cheekii Burgt, a new tree species from Guinea, is described and illustrated. It is a tree to $24 \mathrm{~m}$ high, with a stem diameter to $83 \mathrm{~cm}$, and occurs in forest dominated by tree species of the Leguminosae subfamily Detarioideae, on rocky stream banks and rocky hill slopes, at an altitude of $100-600 \mathrm{~m}$. It is estimated that $1600-$ 2400 mature trees have been seen, in about twelve forest patches; more trees may be present in places not yet visited. One of the localities of the new species is situated at only $46 \mathrm{~km}$ northeast of the centre of the capital Conakry and $6 \mathrm{~km}$ northeast of the town centre of Coyah, part of the Conakry urban agglomeration. Its distribution is $1400 \mathrm{~km}$ further west from the previous westernmost distribution of the genus. The current extent of occurrence is $166 \mathrm{~km}^{2}$. Talbotiella cheekii is here assessed as Endangered (EN) following IUCN Red List categories.

Résumé. Talbotiella cheekii Burgt, décrite et illustrée dans cet article est une nouvelle espèce d'arbre en provenance de la Guinée. C'est un arbre atteignant jusqu'à $24 \mathrm{~m}$ de haut et $83 \mathrm{~cm}$ de diamètre. L'espèce se trouve dans les forêts dominées par des arbres de la sous-famille des Leguminosae Detarioideae, aux abords des ruisseaux rocheux et des pentes rocheuses, à une altitude de 100 à $600 \mathrm{~m}$. On estime qu'entre 1600 et 2400 arbres matures ont été vus dans environ douze parcelles forestières. Il est possible que plus d'arbres soient présents dans des endroits n'ayant pas encore été visités. L'une des localités de la nouvelle espèce est située à seulement $46 \mathrm{~km}$ au Nord-Est du centre de la capitale Conakry et à $6 \mathrm{~km}$ au Nord-Est du centre-ville de Coyah, une partie de l'agglomération de Conakry. Sa distribution est à $1400 \mathrm{~km}$ plus à l'Ouest de la distribution la plus occidentale du genre. La zone d'occurrence actuelle est de $166 \mathrm{~km}^{2}$. Le risque d'extinction de Talbotiella cheekii, ici évalué selon les critères de la liste rouge de l'IUCN, est En danger.

Key Words. Conservation, Endangered species, West Africa.

\section{Introduction}

It came as a great surprise to discover a new tree species of Talbotiella Baker. f. in Guinea. One of the localities of the new species (Burgt 2188) is situated at only $46 \mathrm{~km}$ northeast of the centre of the capital Conakry and $6 \mathrm{~km}$ northeast of the town centre of Coyah, part of the Conakry urban agglomeration. The new species is located $1400 \mathrm{~km}$ further west from the distribution area of Talbotiella gentii Hutch. \& Greenway in Ghana, the westernmost of the eight previously known Talbotiella species (Mackinder et al. 2010b). The new species is found in and near Coyah Préfecture where it occurs gregariously in forested valleys of a sandstone plateau. Although it is very common in some of these valleys, it had never before been collected, perhaps because collectors were focussing on areas further inland, in the Fouta Djalon, where more interesting plant collecting opportunities were thought to exist. The short flowering period may also have contributed to the new species remaining unnoticed for so long. This, however, changed when Martin Cheek, head of the Africa and Madagascar Team of the Identification and Naming Department of the Royal Botanic Gardens, Kew, turned his attention to the last remaining forest patches in the valleys on the sandstone plateau of the Coyah Préfecture. In September 2015, he collected the first specimens of the new species.

The genus Talbotiella was revised by Mackinder et al. (2010b). Eight species were recognised, of which four were newly described and one was

\footnotetext{
Accepted for publication 23 May 2018. Published online 9 June 2018

1 Identification and Naming Department, Africa and Madagascar Team, Royal Botanic Gardens, Kew, Richmond, Surrey, TW9 3AB, UK. e-mail: x.van.der.burgt@kew.org

2 Herbier National de Guinée, Université Gamal Abdel Nasser, Conakry, Guinea.

3 Guinée Biodiversité, Conakry, Guinea.
} 
transferred from Hymenostegia Harms. Seven species are relatively rare trees, occurring in small areas. The eighth species occurs in a larger area but is known from only seven collections. Six species were assessed as critically endangered (CR) and two as endangered (EN). Together, the eight Talbotiella species treated by Mackinder et al. (2010b) occur in Ghana, Nigeria, Cameroon, Gabon and Congo (Brazzaville). In Cameroon, the centre of diversity of the genus, six of the eight species occur, five of which are country endemics (Mackinder et al. 2010b).

The genus Talbotiella is placed in the Leguminosae subfamily Detarioideae (LPWG 2017). The genus is characterised by the unique combination of the presence of imbricate bud scales, persistent petaloid bracteoles, the absence of petals and a pubescent ovary (Mackinder et al. 2010b). The species of the closely related genus Hymenostegia are characterised by the presence of two or three well developed spathulate petals providing a clear distinction from Talbotiella species (Mackinder et al. 2010a). The species of another closely related genus, Plagiosiphon Harms, usually have five well-developed petals, three large and two smaller (Aubréville 1970). The new species is placed in the genus Talbotiella, because it has the combination of morphological characters mentioned for the genus, including an absence of petals on the four known flowering collections.

Talbotiella cheekii Burgt sp. nov. Type: Guinea, Coyah Préfecture, along stream between villages Saliya and Yataraya, 7 April 2017, X. M. van der Burgt, P. M. Haba, A. Diallo $\mathcal{E}$ G. Konomou 2084 (holotype K [K001244000], isotypes B, BM, BR, C, E, EA, ETH, F, FHO, FI, G, GH, H, HBG, HNG, LBV, LE, LISC, MA, MO, MPU, NY, O, P, PRE, S, SING, US, W, WAG, YA).

http://www.ipni.org/urn:lsid:ipni.org:names:77179007-1

Tree to $21 \mathrm{~m}$ high, stem diam. to $83 \mathrm{~cm}$; bole $0.5-7 \mathrm{~m}$ long, straight, cylindrical or fluted, sometimes with buttresses to $1.5 \mathrm{~m}$ high and $1 \mathrm{~m}$ wide; bark light brown with sparse thin flakes; larger branches nearly vertical. Stems densely hairy to glabrescent, hairs to $0.3 \mathrm{~mm}$ long. Bud scales of leafy twigs and inflorescences identical, up to 12 , distichous, imbricate, caducous, coriaceous, not keeled, outer surface hairy around midrib, margins ciliate, inner surface glabrous; proximal scale suborbicular, $1 \times 2 \mathrm{~mm}$, distal scales becoming progressively larger and more papery, apical scale obovate, to $22 \times 6 \mathrm{~mm}$. Stipules (seen on young foliage) in pairs, free, narrowly lanceolate, $6-26 \times 1-2$ $\mathrm{mm}$, apex acute, sometimes auriculate at base, auricle 1 $\times 0.5 \mathrm{~mm}$, outer surface and margins hairy, hairs to $1 \mathrm{~mm}$ long, inner surface glabrous. Leaves paripinnate, $5-9 \times$ $2.5-4 \mathrm{~cm}$; petiole $1.5-3 \mathrm{~mm}$ long, leaf rachis $4-7 \mathrm{~cm}$ long, densely hairy, hairs to $0.5 \mathrm{~mm}$ long. Leaflets sessile, in 9 - 14 pairs per leaf, upper and middle leaflets opposite, lower pairs sub-opposite, largest leaflets on fertile branches $12-22 \times 4-7 \mathrm{~mm}, 2.9-3.4 \times$ longer than wide, smallest leaflets $8 \times 3 \mathrm{~mm}$; leaflets oblong, base and apex asymmetric, apex rounded to slightly emarginate; mature leaflets glabrous on both sides, midvein of young leaflets hairy above, margin sparsely ciliate, lower surface sparsely appressed hairy; midvein running in middle of leaflet; venation above obscure, below clear; $0-2$ glands on the distal half of the lower surface, near the rachis. Inflorescence a $10-18$ flowered raceme, axis $3-6 \mathrm{~cm}$ long including a peduncle about $1 \mathrm{~cm}$ long, peduncle and rachis densely hairy, hairs to $1 \mathrm{~mm}$ long; floral bract white, linear, $9-17 \times 1-1.5 \mathrm{~mm}$ (to $4 \mathrm{~mm}$ wide on the lowest flower of an inflorescence), edges and veins on outer surface hairy, hairs to $0.6(-1) \mathrm{mm}$ long, inner surface glabrous. Flowers: pedicel pink to red, sparsely hairy, hairs to $0.5(-1.2) \mathrm{mm}$ long, portion of pedicel below bracteoles $6-18 \mathrm{~mm}$ long, portion above bracteoles $3-6 \mathrm{~mm}$ long. Bracteoles white, (sub-) opposite, linear, $8-18 \times 0.7-1.6 \mathrm{~mm}$, glabrous, a single trichome to $0.6 \mathrm{~mm}$ long at apex; hypanthium pink to red, campanulate, $2-3 \mathrm{~mm}$ long, longest on the adaxial side, $1.5-2 \mathrm{~mm}$ wide at top, sparse hairy, upper part often glabrous. Sepals 4, white, ovate, cucullate, glabrous, a few hairs at apex, apex rounded, the apex of all 4 sepals may be bilobed, $5-8 \times 3-5 \mathrm{~mm}$, abaxial and adaxial sepals wider than lateral sepals. Petals absent. Stamens 10, filaments white, free, 7 - $13 \mathrm{~mm}$ long, glabrous; anthers orange-brown, elliptic, $1.2-1.4 \mathrm{~mm}$ long. Ovary reddish green to dark red, $3-6 \times 1.5-2 \mathrm{~mm}$, glabrous, the margin densely hairy, hairs to $0.5 \mathrm{~mm}$ long; stipe $2 \mathrm{~mm}$ long, mostly fused to the adaxial side of the hypanthium, ovules 2 , style white to pink, $6-8 \mathrm{~mm}$ long, sparse hairs on lower part, upper part glabrous, stigma capitate. Infructescence axis 3 $6 \mathrm{~cm}$ long, densely hairy, hairs to $1 \mathrm{~mm}$ long, with up to 5 pods, fruiting pedicels $1.4-2.1 \mathrm{~cm}$ long, sparsely hairy, hairs to $0.5 \mathrm{~mm}$ long. Pod 1 - 2seeded, $4.5-7.7 \times 2-3.6 \mathrm{~cm}$, stipe $2 \mathrm{~mm}$ long, beak acuminate, $2 \mathrm{~mm}$ long, upper suture slightly broadened, pod surface glabrous, both sutures with sparse hairs $0.5 \mathrm{~mm}$ long. Seeds brown, disk-shaped, $15-17$ $\times 14-16 \times 4 \mathrm{~mm}$. Seedling hypocotyl $5-8 \mathrm{~cm}$, epicotyl $5-8 \mathrm{~cm}$, two opposite leaves $6-8 \times 3-4$ $\mathrm{cm}$, each with $7-9$ pairs of leaflets, largest leaflets $15-23 \times 6-8 \mathrm{~mm}$. Figs $1-3$. 

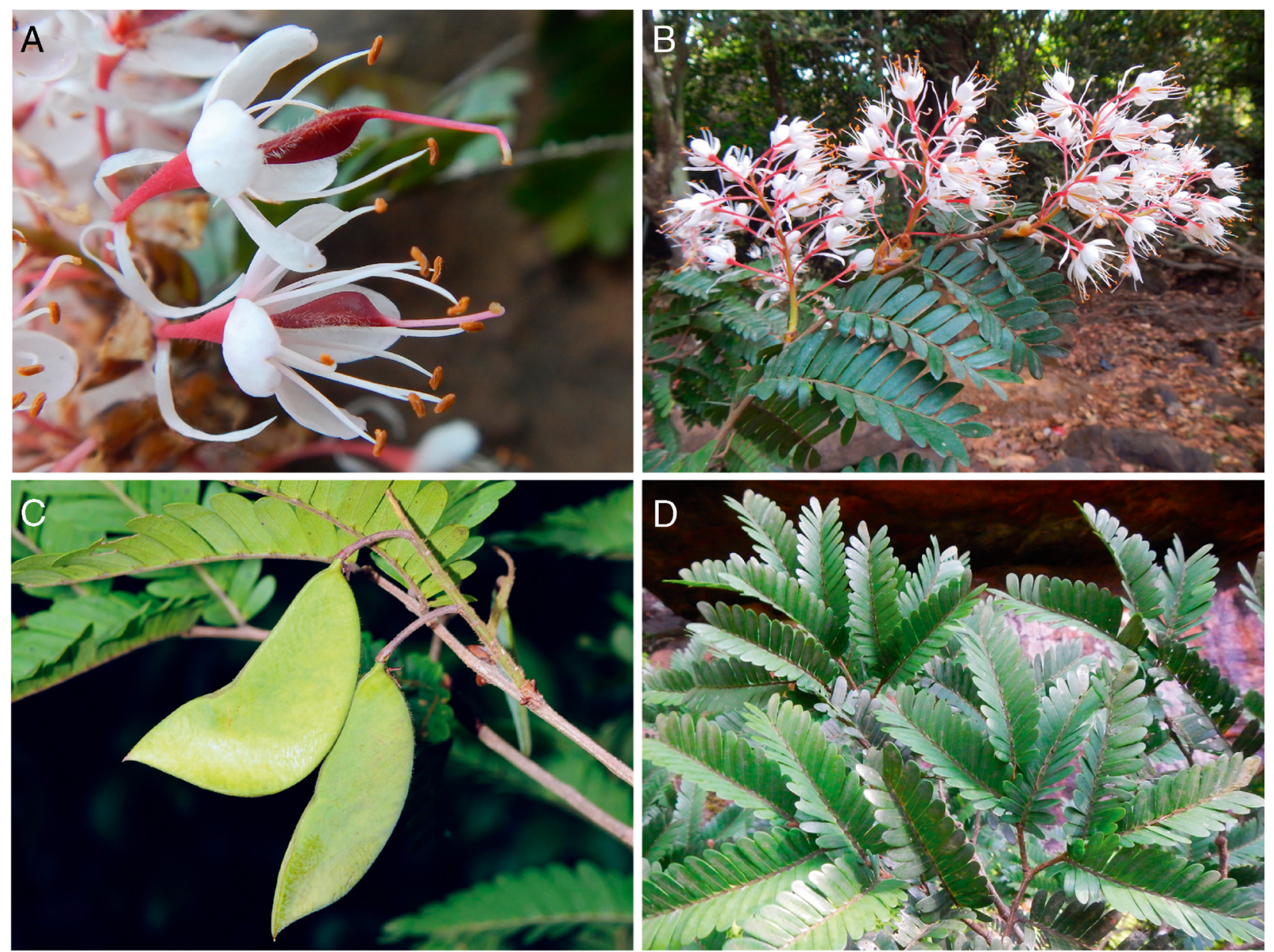

Fig. 1. Talbotiella cheekii. A two flowers; B twig with inflorescences; C infructescence with two fruits; D leaves. A - B from Burgt 2087; C from Molmou 988; D from Burgt 2065. PHOTOS: A, B, D XANDER VAN DER BURGT; C MARTIN CHEEK.

RECOGNITION. Talbotiella cheekii is morphologically similar to T. batesii Baker f. The pedicels of T. cheekiiare pink to red, 9 - $24 \mathrm{~mm}$ long; the bracteoles are $8-15 \times 0.7-$ $1.5 \mathrm{~mm}$ (the pedicels of T. batesiiare white, $4-10.5 \mathrm{~mm}$ long; the bracteoles are $6-8.5 \times 1.1-2.5 \mathrm{~mm}$ ). The ovary of T. cheekii is reddish green to dark red, and glabrous with only the edges densely hairy (the ovary of T. batesii is pale pink, and densely hairy). The pod of $T$. cheekii is glabrous, the sutures sparsely hairy (the pod of T. batesii has the surfaces and suture moderately puberulous). The leaflet apex of T. cheekii is rounded to slightly emarginate (the leaflet apex of T. batesii is acute).

DISTRIBUTION. Guinea (Map 1). Talbotiella cheekii occurs on the sandstone plateau in the northern part of Coyah Préfecture. Its distribution just extends into Dubreka and Kindia Préfectures.

SPECIMENS EXAMINED. GUINEA. Coyah Préfecture, valley in sandstone plateau SE of Kouriya, 9 $45^{\prime} 29.1^{\prime \prime}$, 13 18'06.0"W, 350 m, sterile, 11 Oct. 2016, Burgt 2065 (BR, G, HNG, K, MO, P, PRE, WAG); valley in sandstone plateau E of Kouriya, $9^{\circ} 46^{\prime} 41.6^{\prime \prime} \mathrm{N}$, $13^{\circ} 16^{\prime} 42.0^{\prime \prime} \mathrm{W}, 260 \mathrm{~m}$, seedlings, 12 Oct. 2016, Burgt
2068 (BR, HNG, K, MO, P, WAG); along stream between villages Saliya and Yataraya, 9 $45^{\prime} 23.7^{\prime \prime} \mathrm{N}$, 13¹5'41.4"W, 120 m, fl., 7 April 2017, Burgt 2084 (holotype $\mathrm{K}$; isotypes $\mathrm{B}, \mathrm{BM}, \mathrm{BR}, \mathrm{C}, \mathrm{E}, \mathrm{EA}, \mathrm{ETH}, \mathrm{F}, \mathrm{FI}$, FHO, G, GH, H, HBG, HNG, LBV, LE, LISC, MA, MO, MPU, NY, O, P, PRE, S, SING, US, W, WAG, YA); along small stream SW of Kaporo Village, 9 $43^{\prime} 01.6^{\prime \prime} \mathrm{N}$, 13¹6'51.1"W, 130 m, fl., 8 April 2017, Burgt 2087 (B, BR, G, HNG, K, LISC, MO, NY, P, PRE, SING, WAG); on hill slope just $\mathrm{E}$ of Sagouya Village, $9^{\circ} 42^{\prime} 38.8^{\prime \prime} \mathrm{N}$, $13^{\circ} 16^{\prime} 47.4^{\prime \prime} \mathrm{W}, 190$ m, fl., 10 April 2017, Burgt 2093 (B, BR, G, HNG, K, LISC, MO, P, PRE, WAG); along rocky stream $3.5 \mathrm{~km}$ NE of Malassi Village, 9 $9^{\circ} 1^{\prime} 33.4^{\prime \prime} \mathrm{N}$, $13^{\circ} 13^{\prime} 42.2^{\prime \prime}$, 110 m, old inflor., 13 April 2017, Burgt 2097 (B, BR, G, HNG, K, LISC, MO, P, PRE, WAG); Kindia Préfecture, Plateau de Tassing above Fossikouré Village, 941'59.1"N, 13¹0'41.7"W, $540 \mathrm{~m}$, sterile, 8 Dec. 2017, Burgt 2187 (BR, HNG, K, MO, P, SERG, WAG); Coyah Préfecture, vertical sandstone cliff $50 \mathrm{~m}$ above stream at the checkpoint near Pont KK, 9 ${ }^{\circ} 45^{\prime} 05.5^{\prime \prime} \mathrm{N}, 13^{\circ} 21^{\prime} 27.6^{\prime \prime} \mathrm{W}, 150 \mathrm{~m}$, fl., 9 Dec. 2017, Burgt 2188 (B, BR, G, HNG, K, LISC, MO, P, PRE, 
A
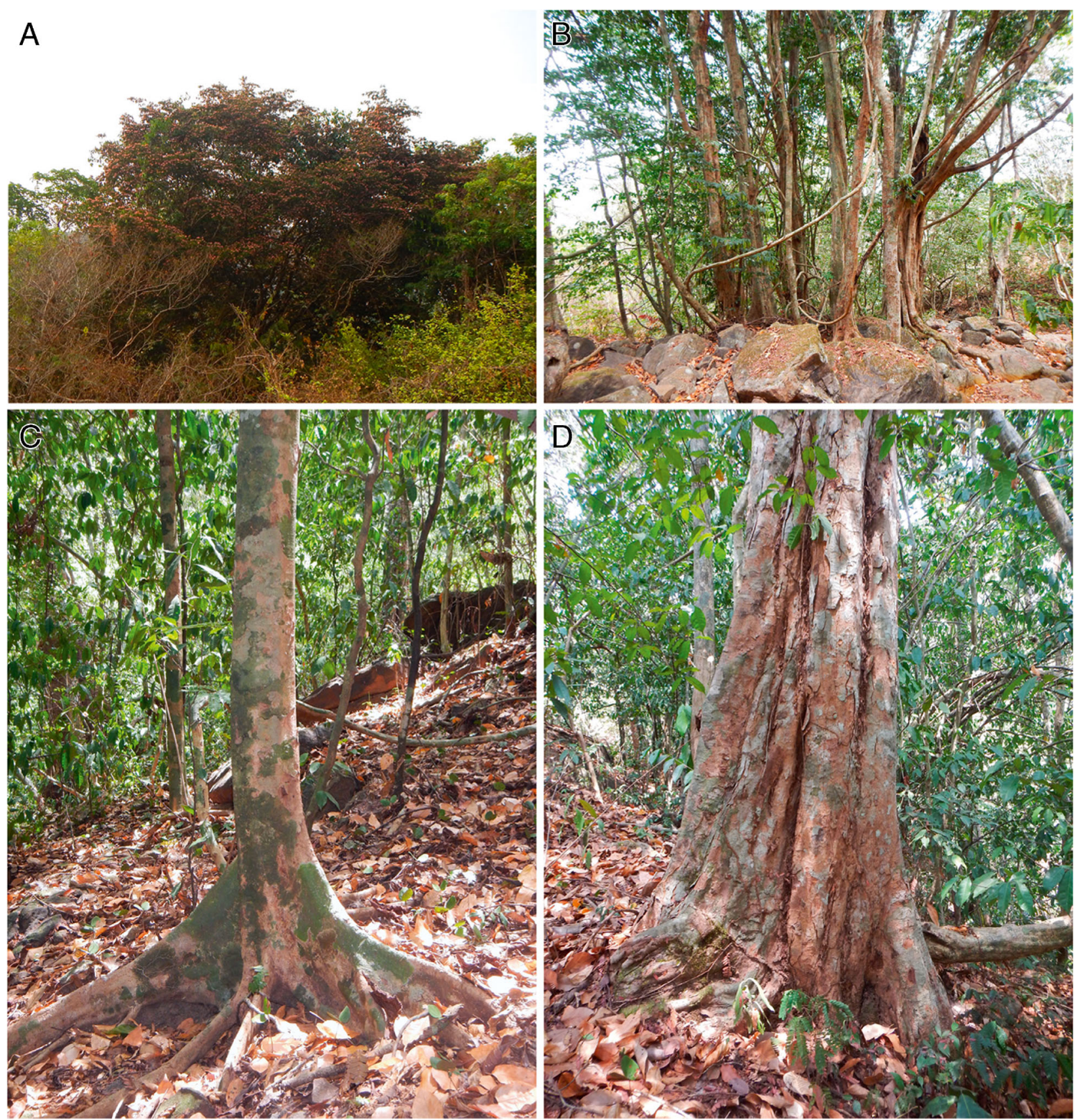

Fig. 2. Talbotiella cheekii. A crown of tree in flower; B group of trees; $C$ stem of a young tree; D stem of an old tree. A from Burgt 2093; B - D not collected. PHOTOS: XANDER VAN DER BURGT.

SERG, WAG); Kakiwoundi Forest, 943'46"N, $13^{\circ} 17^{\prime} 28.2^{\prime \prime} \mathrm{W}, 250 \mathrm{~m}$, sterile, 28 Sept. 2015, Cheek 18133 (HNG, K, WAG); valley in sandstone plateau SE of Kouriya, $9^{\circ} 45^{\prime} 29^{\prime \prime} \mathrm{N}, 13^{\circ} 18^{\prime} 16.7^{\prime \prime} \mathrm{W}, 188 \mathrm{~m}$, sterile, 28 Sept. 2015, Cheek 18190 (HNG, K); Dubreka Préfecture, plateau E of Dobiro Village, $9^{\circ} 50^{\prime} 37.5^{\prime \prime} \mathrm{N}$, $13^{\circ} 26^{\prime} 16.8^{\prime \prime} \mathrm{W}, 420 \mathrm{~m}$, sterile, 10 Dec. 2017, Haba 1095 (HNG, K, WAG); Coyah Préfecture, plateau S of Kouriya, $9^{\circ} 45^{\prime} 05.5^{\prime \prime} \mathrm{N}, 13^{\circ} 20^{\prime} 28^{\prime \prime} \mathrm{W}, 200 \mathrm{~m}$, fr., 10 Sept. 2017, Konomou 294 (HNG, K, WAG); Kakiwoundi
Forest, $9^{\circ} 43^{\prime} 45.9^{\prime \prime} \mathrm{N}, 13^{\circ} 17^{\prime} 17.8^{\prime \prime} \mathrm{W}, 220 \mathrm{~m}$, fr., 8 June 2016, Molmou 988 (HNG, K, WAG).

HABITAT. Talbotiella cheekii occurs in closed-canopy semi-deciduous forest on rocky stream banks and rocky hill slopes, alt. $100-600 \mathrm{~m}$. The general precipitation is about $2800 \mathrm{~mm} / \mathrm{y}$ but may be higher or lower in the valleys where the trees are found, due to orographic influences on precipitation levels. The climate is strongly seasonal with a pronounced dry season from December to April. Talbotiella cheekii 


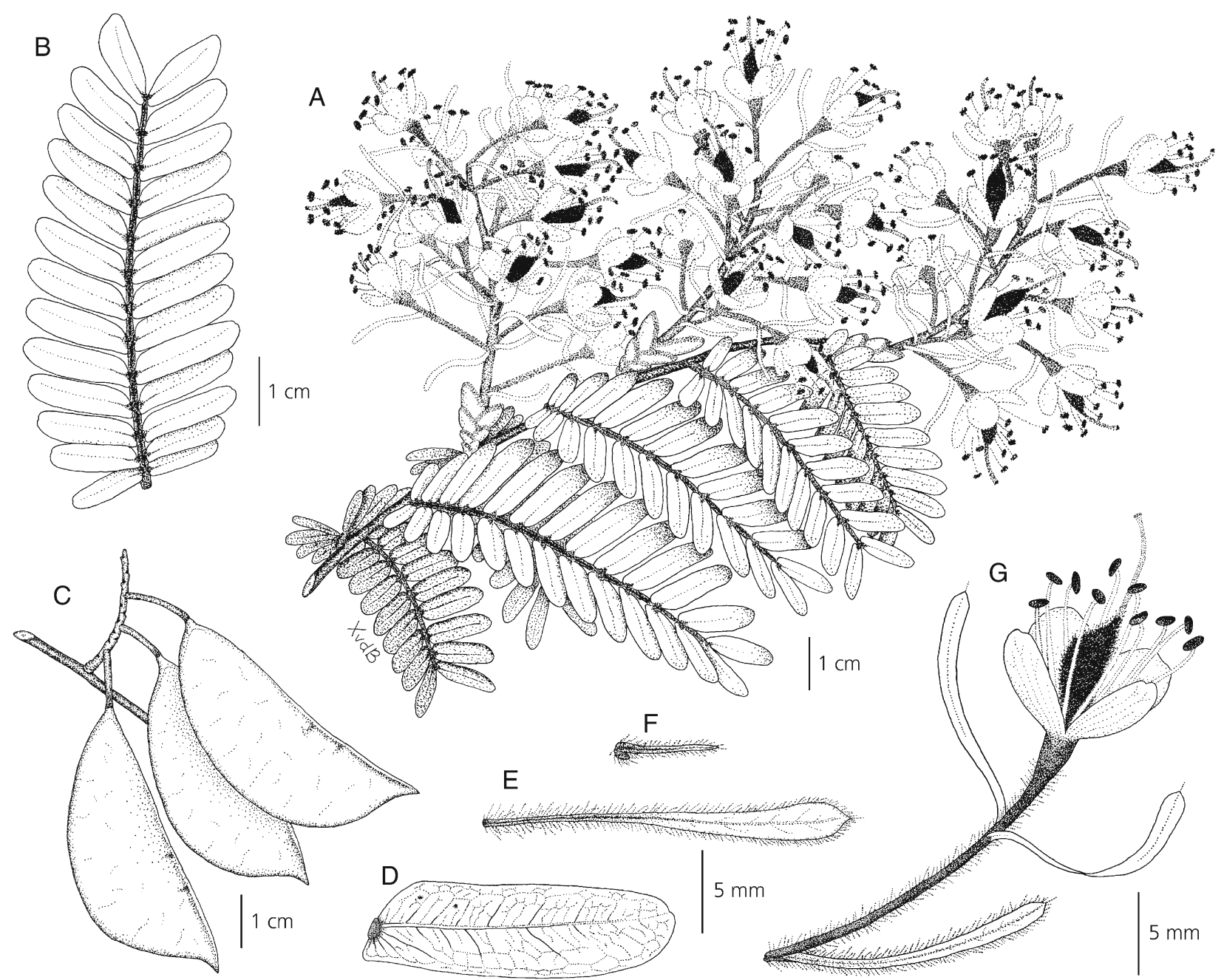

Fig. 3. Talbotiella cheekii. A branch with inflorescences; B leaf upper surface; $C$ infructescence with three fruits; D leaflet lower surface showing two glands; E stipule; F auriculate stipule; G flower. A, E, G from Burgt 2087; B, D, F from Burgt 2065; C from Molmou 988. DRAWN BY XANDER VAN DER BURGT.

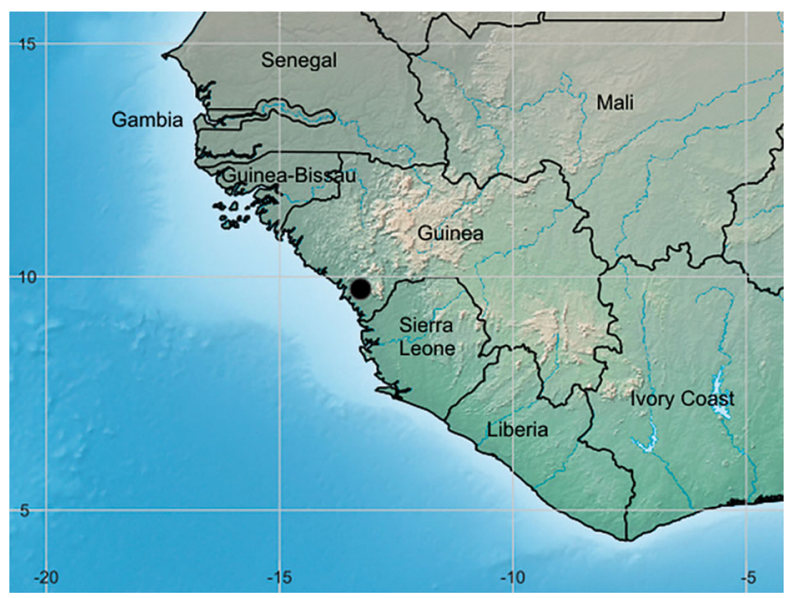

Map 1. Distribution of Talbotiella cheekii Burgt sp. nov. in West Africa occurs gregariously, in Detarioideae-dominated forest. The species occurs with the four Detarioideae species Cryptosepalum tetraphyllum (Hook. f.) Benth., Guibourtia copallifera Benn., Gilbertiodendron aylmeri (Hutch. \& Dalziel) J. Léonard and Tessmannia baikiaeoides Hutch. \& Dalziel.

CONSERVATION STATUS. There is not much forest left in Coyah Préfecture. Slash-and-burn farming, annual dryseason grass fires damaging forest edges, and urban development have much reduced the area under forest cover. Talbotiella cheekii was found in about twelve forest patches, between 1 and 7 ha in size, situated on steep rocky slopes or along rocky streams. Numerous seedlings, saplings and juvenile trees are present in these forest patches. Trees will not survive forest fires, although they may survive coppicing at about $1 \mathrm{~m}$ high which the local farmers often practice when they convert forest into farmland. The main stem of T. cheekii trees is usually too short and fluted to be useful as construction 
timber. Poles are made from juvenile trees with a straight trunk and used in the construction of houses. Several T. cheekii trees were observed broken where adjacent trees had been logged.

Talbotiella cheekii classifies as Endangered under IUCN (2017) criterion B1. The extent of occurrence is $166 \mathrm{~km}^{2}$, calculated with Geocat (2018) from the 13 cited specimens and 10 field observations. Additional forest patches exist in localities which, to date, are unvisited; both within and near the current extent of occurrence. The extent of occurrence may therefore increase because of future surveys but will almost certainly remain within the IUCN (2017) EN B1 thresholds of $100-5000 \mathrm{~km}^{2}$. The number of mature trees seen by the authors is estimated at 1600 -2400 . The total number of mature trees is estimated at $5000-10000$. The twelve forest patches are located near seven different villages or suburbs; therefore, the species is supposed to occur in seven locations (IUCN 2017). However, there is a reduced probability of recolonisation; therefore $T$. cheekii may be considered severely fragmented and IUCN criterion B1a still indicates EN (IUCN 2017). Talbotiella cheekii trees are found in small and often relatively isolated subpopulations, most of which are located near farmland or near land divided up for urban development. Some of these small subpopulations may go extinct soon. The ballistic seed dispersal method of $T$. cheekii (see the notes section below) results in a relatively short (probably less than $30 \mathrm{~m}$ ) and strictly limited maximum seed dispersal distance. Except for dispersal by water downstream in gullies and streams, longdistance seed dispersal methods are unknown for T. cheekii and related Detarioideae tree species (Burgt 1997; Burgt pers. obs.).

Talbotiella cheekii also classifies as Endangered under IUCN criterion A. The authors have seen several patches of farmland on rocky slopes and several galleries of secondary vegetation along rocky streams, where only a few damaged $T$. cheekii trees were present. Presumably there were once many more trees there, since $T$. cheekii always occurs gregariously in natural forests. If the generation length is roughly estimated to be 40 years, the reduction of forest cover in the region where $T$. cheekii occurs is estimated to have resulted in $60 \%$ to $90 \%$ population reduction of T. cheekii trees over the past three generations. In the future, the population reduction will likely continue but may become somewhat less, because some of the remaining trees were growing in places unsuitable for farming and relatively safe from forest fires: amongst large rocks along streams and on steep cliffs. However, if the current rate of deforestation in Coyah Préfecture continues, the population reduction of $T$. cheekii may well be over $50 \%$ during the next three generations.

Talbotiella cheekii is here assessed, following IUCN Red List categories, as Endangered, EN A2c+3c; Blab(iii,iv,v) (IUCN 2017). Conservation actions are planned to protect the species. Martin Cheek is working with the Guinean Ministère de l'Environnement des Eaux et Forêts to increase protection of the region where $T$. cheekii occurs, as well as other regions with rare plant species. National and local authorities will be informed about the conservation importance of the species. Conservation posters will be prepared and distributed. The tree may be planted in gardens. Seeds will be collected for Kew's Millennium Seed Bank; although it is not certain that the seeds are orthodox since they are dispersed at the height of the rainy season.

PHENOLOGY. Talbotiella cheekii flowers and leaf flushes in April, at the end of the dry season. All flowers of an inflorescence open at the same time (Fig. 1B); the few flower buds present on Burgt 2084, the first of the flowering collections, were unable to open because they were insect infested. All mature trees of T. cheekii were flowering simultaneously on the $7^{\text {th }}$ and $8^{\text {th }}$ of April 2017. No observations were made on the $6^{\text {th }}$ of April or before that date. On the $9^{\text {th }}$ and $10^{\text {th }}$ of April only wilted flowers were present. The flowering tree collected on $9^{\text {th }}$ of December 2017, Burgt 2188, was badly damaged by fire and presumably therefore flowering, as there were no other trees flowering at that time.

In June and July fruits are mature and seeds are dispersed. The seeds germinate within a week after dispersal. All species of Talbotiella of which fruits are known, disperse their seeds ballistically (Mackinder et al. 2010b). The seeds of T. cheekii are also dispersed in this way, with the drying valves of a pod curling in opposite directions. Talbotiella cheekii trees are gregarious (Fig. 2B) and this tendency is probably related to the relatively short and strictly limited maximum dispersal distance of the ballistic seed dispersal within a forest environment.

ETYMOLOGY. Talbotiella cheekii is named after Dr Martin Cheek, Head of the Africa \& Madagascar Team in the Identification and Naming Department of the Royal Botanic Gardens, Kew. The new species was discovered thanks to his long-standing commitment to the study of African plants. He has been studying the flora of Guinea on field expeditions since 2005, supported the restoration of the National Herbarium of Guinea, and described a new genus and four new species from the country (Cheek \& Burgt 2010; Cheek \& Haba 2016a, 2016b; Cheek \& Williams 2016; Cheek et al. 
2016). He is also involved in the designation of new protected areas in Guinea as part of Kew's Tropical Important Plant Areas (TIPAs) Project (Darbyshire et al. 2017) and is supervising a Darwin Initiativefunded project on rare plant species conservation in the country.

VERNACULAR NAME. Linsonyi (from Burgt 2084); Meni (from Molmou 988); Wonkifong wouri khorohoi (from Burgt 2097), translated as the "Tree with hard wood from Wonkifong". This last name was proposed by the people of Malassi village when the trees were shown to them. All three names are in the Susu language.

USES. The wood is fine-grained, with a density of $\mathrm{c}$. $900 \mathrm{~kg} \mathrm{~m}^{-3}$. A pole made from the wood can be used as a pestle to pound food in a mortar (from Burgt 2084). A decoction from the leaves is used to remove the magical powers from confessed sorcerers (from Molmou 988).

NOTES. Talbotiella cheekii is characterised by the long pedicels, pink to red in colour, the long and narrow bracteoles, the glabrous pod (only the margin sometimes has a few hairs) and the rounded to slightly emarginate leaflet apex. Apart from this, the leaves and leaflets of T. cheekii and T. batesii are more or less similar; both species have 9 - 14 pairs of leaflets per leaf. Of all previously described Talbotiella species, T. cheekii is morphologically most similar to T. batesii. This is remarkable, because $T$. batesii is the easternmost species of Talbotiella, occurring in southeast Cameroon, northeast Gabon and north Congo (Brazzaville), at 2900 to $3100 \mathrm{~km}$ distance from T. cheekii, the westernmost species. A molecular analysis might show, however, that $T$. cheekii is more closely related to a different species, for example to $T$. gentii from Ghana, geographically the nearest of the eight existing Talbotiella species.

Two more plant species from the Leguminosae family have been newly discovered in Guinea in recent years: Eriosema triformum Burgt (Burgt et al. 2012), a pyrophytic herb with unifoliolate leaves, from submontane grassland, endemic to the Pic de Fon area in the Simandou Range, and Gilbertiodendron tonkolili Burgt \& Estrella (Estrella et al. 2012), a tree from well-drained sandy and/or rocky soils on river banks and forest patches, first discovered in Sierra Leone, and later found to occur also in Guinea (e.g. the specimens Cheek 16172, 16583 and 16614; all in HNG and K).

\section{Acknowledgements}

The new species was discovered thanks to the Garfield Weston Foundation, through their funding of the 'Global Tree Seed Bank Project' of Kew's Millennium Seed Bank Partnership. This enabled three seed collecting expeditions to Guinea, during which the type specimen of the new species was collected. Rio Tinto
Guinea supported an earlier expedition, during which the first, sterile specimens of Talbotiella cheekii were collected. Mr Abdoulaye Yéro Baldé, Ministre of the Guinean Ministère de l'Enseignement Supérieur et de la Recherche Scientifique, and Dr Binko Mamady Touré, Secrétaire Général of the same Ministry, are thanked for co-operation. Colonel Namory Keita, the Directeur National des Eaux et Forêts and Mr Mamadou Bella Diallo, Point Focal CITES, Direction National des Eaux et Forêts are thanked for authorisation of the export of the plant specimens.

Open Access This article is distributed under the terms of the Creative Commons Attribution 4.0 International License (http://creativecommons.org/ licenses/by/4.0/), which permits unrestricted use, distribution, and reproduction in any medium, provided you give appropriate credit to the original author(s) and the source, provide a link to the Creative Commons license, and indicate if changes were made.

\section{References}

Aubréville, A. (1970). Flore du Cameroun 9, Légumineuses-Césalpinioidées. Muséum national d'Histoire naturelle, Paris.

Burgt, X. M. van der. (1997). Explosive seed dispersal of the rainforest tree Tetraberlinia moreliana (Leguminosae-Caesalpinioideae) in Gabon. J. Trop. Ecol. 13: 145 - 151.

, Haba, P. K., Haba, P. M. \& Goman, A. S. (2012). Eriosema triformum (Leguminosae: Papilionoideae), a new unifoliolate species from Guinea, West Africa. Kew Bull. 67: 263 - 271.

Cheek, M. \& van der Burgt, X. M. (2010). Gymnosiphon samoritoureanus (Burmanniaceae) a new species from Guinea, with new records of other achlorophyllous heteromycotrophs. Kew Bull. 65: 83 - 88 .

\& Haba, P. M. (2016a). Inversodicraea Engl. resurrected and $I$. pepehabai sp. nov. (Podostemaceae), a submontane forest species from the Republic of Guinea. Kew Bull. 71: 55. \& ____ (2016b). Spiny African Allophylus

(Sapindaceae): a synopsis. Kew Bull. 71: 57. \& Williams, T. (2016). Psychotria samoritourei (Rubiaceae), a new liana species from Loma-Man in Upper Guinea, West Africa. Kew Bull. 71: 19.

Challen, G., Lebbie, A., Banks, H., Barberá, P. \& Riina, R. (2016). Discovering Karima (Euphorbiaceae), a new Crotonoid genus from West Tropical Africa long hidden within Croton. PLoS ONE 11(4): e0152110.

Darbyshire, I., Anderson, S., Asatryan, A., Byfield, A., Cheek, M., Clubbe, C., Ghrabi, Z., Harris, T., Heatubun, C. D., Kalema, J., Magassouba, S., McCar- 
thy, B., Milliken, W., Montmollin, B. d., Nic Lughadha, E., Onana, J. M., Saıdou, D., Sarbu, A., Shrestha, K. \& Radford, E. A. (2017). Important Plant Areas: revised selection criteria for a global approach to plant conservation. Biodivers. Eं Conserv. 26: 1767 - 1800.

Estrella, M. de la, Burgt, X. M. van der, Mackinder, B. A., Devesa, J. A., Matthew, J. S. \& Hawthorne, W. D. (2012). Gilbertiodendron tonkolili sp. nov. (Leguminosae - Caesalpinioideae) from Sierra Leone. Nord. J. Bot. 30: 136 - 143.

Geocat (2018). Geospatial Conservation Assessment Tool. http://geocat.kew.org. Accessed April 2018.

IUCN Standards and Petitions Subcommittee (2017). Guidelines for using the IUCN Red List Categories and Criteria. Version 13.
LPWG (Legume Phylogeny Working Group) (2017). A new subfamily classification of the Leguminosae based on a taxonomically comprehensive phylogeny. Taxon 66(1): $44-77$.

Mackinder, B. A., Wieringa, J. J., Lunenburg, I. \& Banks, H. (2010a). Clarifying the generic limits of Talbotiella and Hymenostegia (Detarieae, Caesalpinioideae, Leguminosae). In: X. van der Burgt, J. van der Maesen \& J.-M. Onana (eds), Systematics and Conservation of African Plants, pp. $43-$ 56. Royal Botanic Gardens, Kew. \& Burgt, X. M. van der. (2010b). A revision of the genus Talbotiella Baker f. (Caesalpinioideae: Leguminosae). Kew Bull. 65: 401 - 420 . 